\section{(2) \\ OPEN ACCESS}

\title{
Rare presentation of De Garengeot hernia in a 77-year-old woman
}

\author{
Marjan Raad, Tord Høgsand, Muhammed Saeed Qureshi, James Pitt
}

Department of General Surgery, Ipswich Hospital NHS Trust, Ipswich, UK

\section{Correspondence to \\ Dr Marjan Raad;}

marjan.raad@nhs.net

Accepted 20 March 2020

\section{SUMMARY}

A 77-year-old woman presented with a rare surgical phenomenon known as De Garengeot hernia. This unique presentation occurs due to the presence of a vermiform appendix in a femoral hernia sac. The patient presented with right-sided groin pain and a partially reducible hernia; she was otherwise haemodynamically stable and denied fevers, nausea and vomiting. The diagnosis was confirmed with CT which demonstrated a right-sided femoral hernia containing a perforated tip of the appendix. The patient urgently underwent an open appendectomy and open right femoral hernia repair using the modified McEvedy's incision.

\section{BACKGROUND}

We report a rare case of femoral hernia, De Garengeot hernia which contained appendix in the hernial sac. Femoral hernias, which are less common than inguinal, are more often found in women. ${ }^{1}$ This is a rare case and usually presents with diagnostic and therapeutic challenges. De Garengeot hernia, and the incidence of appendicitis in this type of hernia are as low as $0.08 \%-0.13 \%$. $^{2}$ This hernia must be differentiated from Amyand hernia, which is the presence of the appendix inside an inguinal hernia. $^{3}$

\section{CASE PRESENTATION}

A 77-year-old woman presented to the surgical admissions unit with right-sided groin pain. She denied fevers, nausea, vomiting, bowel or any urinary symptoms and did not have any recent trauma.

On examination, she had right groin tenderness with a partially reducible femoral hernia, she was haemodynamically stable. Her bloods showed a white cell count of $11.2 \times 10^{9} / \mathrm{L}$ and C-reactive protein of 84 ; the rest of the bloods were within range. Abdominal X-ray showed faecal loading. The impression was a right-sided incarcerated femoral hernia.

Check for updates

(c) BMJ Publishing Group Limited 2020. Re-use permitted under CC BY-NC. No commercial re-use. See rights and permissions. Published by BMJ.

To cite: Raad M, Høgsand T, Qureshi MS, et al. BMJ Case Rep 2020;13:e232419. doi:10.1136/bcr-2019232419

\section{INVESTIGATIONS}

Ultrasound can reveal the bowel contents in the hernia $\mathrm{sac}^{4}$; however, the patient presented in an acute setting and CT scanning remains the gold standard for diagnosis. She had a CT scan of abdomen and pelvis which showed she had a right femoral hernia containing the appendix (figure 1). The appendix was perforated at its tip within the sac, significant local inflammatory and soft-tissue stranding (figure 2).

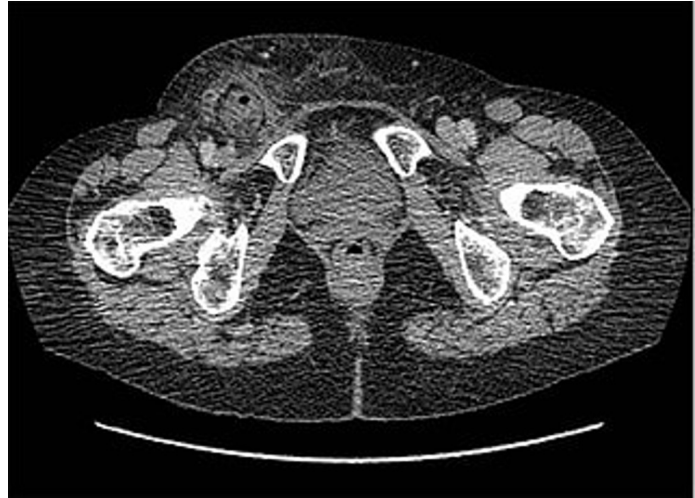

Figure 1 CT scan of abdomen-axial.

\section{DIFFERENTIAL DIAGNOSIS}

Acute appendicitis should be considered as a differential diagnosis in patients who present with right groin pain. De Garengeot hernias is rare; however, it is important to identify preoperatively which helps planning surgery and obtaining well-informed consent from the patient.

\section{TREATMENT}

Under the diagnosis of incarceration of the right femoral hernia containing perforated appendix, the patient was taken to the emergency theatre and had an open appendectomy and open repair of right femoral hernia. Using modified McEvedy's incision, contents were reduced containing inflamed and gangrenous appendix and bruised omentum, hernia sac dissected and sac opened. Appendectomy was done and femoral canal obliterated from abdominal side with suture.

\section{OUTCOME AND FOLLOW-UP}

The patient recovered well postoperatively and discharged the same day without any complications.

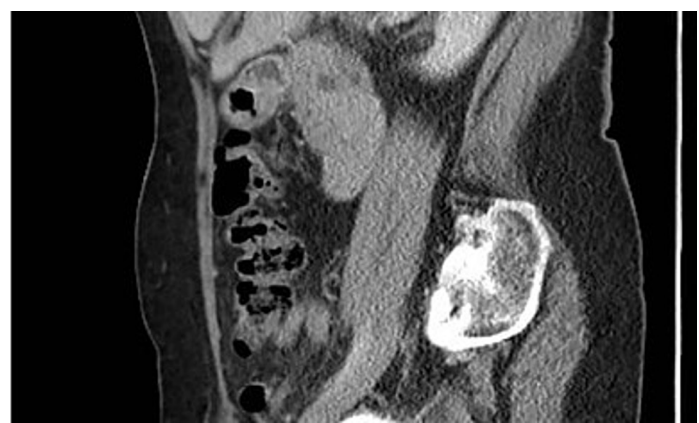

Figure 2 CT scan of abdomen. 


\section{Learning points}

Acute appendicitis should be considered as differential diagnosis in patients who present with right-sided groin pain.

- It is important to recognise De Garengeot hernia preoperatively.

- CT scanning is an important aid to lead to a diagnosis which can aid in planning surgery.

- Obtain a well-informed consent from the patient.
Funding The authors have not declared a specific grant for this research from any funding agency in the public, commercial or not-for-profit sectors.

Competing interests None declared.

Patient consent for publication Obtained.

Provenance and peer review Not commissioned; externally peer reviewed.

Open access This is an open access article distributed in accordance with the Creative Commons Attribution Non Commercial (CC BY-NC 4.0) license, which permits others to distribute, remix, adapt, build upon this work non-commercially, and license their derivative works on different terms, provided the original work is properly cited and the use is non-commercial. See: http://creativecommons.org/ licenses/by-nc/4.0/.

She has been asymptomatic since and was discharged after her 6-week follow-up.

Contributors All authors stated above have provided substantial contribution towards this abstract and have met the conditions required. MR: writing abstract, planning of case report. TH: research into hernia and contributing to finalising abstract, design. MSQ: operating on patient and discovering hernia, planning of case report. JP: operating on patient, overseeing project.

\section{REFERENCES}

1 Isaacs LE, Felsenstein CH. Acute appendicitis in a femoral hernia: an unusual presentation of a groin mass. J Emerg Med 2002;23:15-18.

2 Rajan SS, Girn HRS, Ainslie WG. Inflamed appendix in a femoral hernial sac: de Garengeot's hernia. Hernia 2009;13:551-3.

3 Ardeleanu V, Chicos S, Tutunaru D, et al. A rare case of acute abdomen: Garengeot hernia. Chirurgia 2013;108:896-9.

4 Filatov J, libitzki A, Davidovitch S, et al. Appendicitis within a femoral hernia: sonographic appearance. J Ultrasound Med 2006;25:1233-5.

Copyright 2020 BMJ Publishing Group. All rights reserved. For permission to reuse any of this content visit

https://www.bmj.com/company/products-services/rights-and-licensing/permissions/

BMJ Case Report Fellows may re-use this article for personal use and teaching without any further permission.

Become a Fellow of BMJ Case Reports today and you can:

- Submit as many cases as you like

- Enjoy fast sympathetic peer review and rapid publication of accepted articles

- Access all the published articles

- Re-use any of the published material for personal use and teaching without further permission

Customer Service

If you have any further queries about your subscription, please contact our customer services team on +44 (0) 2071111105 or via email at support@bmj.com.

Visit casereports.bmj.com for more articles like this and to become a Fellow 